\title{
Tyrosine kinase activity of insulin receptors from an insulin-resistant patient with leprechaunism
}

\author{
A. Cama and S. I. Taylor \\ Biochemistry and Molecular Pathophysiology Section, Diabetes Branch, National Institute of Diabetes, Digestive and Kidney Diseases, \\ National Institutes of Health, Bethesda, Maryland, USA
}

\begin{abstract}
Summary. Defects in insulin receptor function can impair the response of target cells to insulin. Previously we have described an insulin resistant patient (leprechaun/Ark-1) with qualitative abnormalities in insulin binding suggestive of a structural defect in her insulin receptors. In the present work, we have studied the tyrosine kinase activity associated with insulin receptors from cultured Epstein-Barr virus-transformed lymphocytes. In studies of insulin receptors from leprechaun/Ark-1, we observed that both the magnitude and the dose-dependency of insulin's effect to stimulate the tyrosine kinase activity were normal. This suggests that the defect causing this patient's insulin resistance is independent of the receptor-associated tyrosine kinase. In the course of these
\end{abstract}

studies, we noted that an anti-receptor antiserum (B-d) had a markedly decreased ability to immunoprecipitate insulin receptors from leprechaun/Ark-1. This observation further supports our previous conclusion that the insulin receptor from leprechaun/Ark-1 is abnormal in structure. Moreover, it emphasizes the importance of choosing anti-receptor antisera which are equally effective at immunoprecipitating receptors from both patients and normal subjects when the anti-receptor antisera are employed as reagents in investigations of receptors from insulin-resistant patients.

Key words: Insulin receptor, tyrosine kinase, insulin resistance, anti-receptor antibodies, leprechaunism.
Insulin resistance plays an important role in the pathogenesis of several disease states, including Type 2 (noninsulin-dependent) diabetes mellitus. Recent evidence supports the hypothesis that activation of the insulin receptor-associated tyrosine kinase mediates the biological action of insulin [1-3]. Moreover, several reports have suggested that defects in the receptor-associated tyrosine kinase may cause insulin resistance in some patients [4-8].

Previously we have described a patient with extreme insulin resistance (leprechaun/Ark-1) whose cultured Epstein-Barr virus-transformed lymphocytes possess a normal number of insulin receptors [9-12]. However, the receptors exhibit multiple qualitative abnormalities in insulin binding including increased affinity and decreased sensitivity to changes in temperature and $\mathrm{pH}$, suggesting an abnormality in receptor structure. Moreover, because the patient's receptor bound insulin with increased affinity, the insulin resistance was not caused by a failure to bind insulin, but more likely by a defect in transmembrane signalling. In the present investigations, we have inquired whether the defect in transmembrane signalling might be caused by a defect in the receptor's tyrosine kinase ac- tivity. Because insulin had a normal effect to stimulate tyrosine kinase activity of receptors from leprechaun/ Ark-1, we conclude that the cause of insulin resistance is likely to be independent of kinase activation. In addition, we observed that anti-receptor antiserum (B-d) had a decreased ability to bind to insulin receptors from leprechaun/Ark-1. These data provide further evidence to support the previous conclusion that insulin receptors of leprechaun/Ark-1 have an intrinsic structural abnormality. Moreover, because anti-receptor antibodies have frequently been employed as reagents to study insulin receptors from insulin resistant patients, our studies draw attention to an important methodological pitfall which must be avoided in this type of study.

\section{Subjects and methods}

\section{Patients and cell lines}

The insulin resistant patient referred to as leprechaun/Ark-1 is a young girl with leprechaunism who has been the subject of several publications [9-15]. She exhibited several of the classical phenotypic features of leprechaunism, including intrauterine growth retardation (weight 2,600 $\mathrm{g}$ at birth), extreme insulin resistance, hyperinsulin- 


\section{REDUCED NON REDUCED}

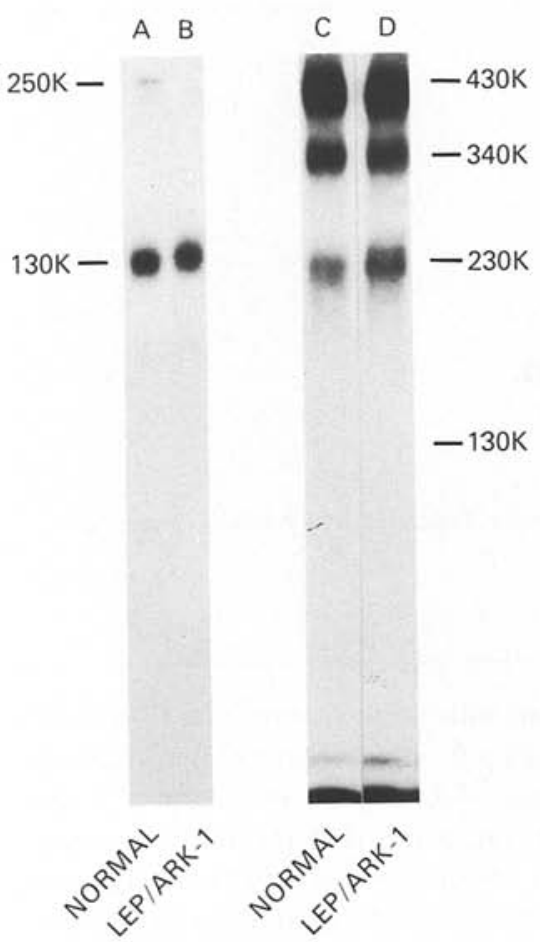

Fig.1. Affinity labelling of insulin receptors in cultured lymphocytes. Insulin receptors on cultured lymphocytes were affinity-labelled as described in Methods and analyzed by SDS-polyacrylamide gel electrophoresis with (lanes A, B) or without (lanes C, D) prior reduction of disulfide bonds by $\beta$-mercaptoethanol. Different percentages of polyacrylamide were used in lanes A-B (7.5\%) and lanes C-D (5\%). Samples in lanes A and B were immunoprecipitated with $\alpha$-IR-1 monoclonal antireceptor antibody [20]. Samples in lanes C and D were analyzed by SDS-polyacrylamide gel electrophoresis directly after solubilisation of the cells.

aemia (insulin levels ranging from $125-10,000 \mu \mathrm{U} / \mathrm{ml}$ ) and fasting hypoglycaemia [14]. The mother had normal glucose tolerance but similar qualitative defects in insulin binding to Epstein-Barr virustransformed lymphocytes. The father had a moderate degree of insulin resistance and hyperinsulinaemia (insulin levels ranging from $90-485 \mu \mathrm{U} / \mathrm{ml}$; fasting glucose $3.9 \mathrm{~mol} / 1)$. There was no history of consanguinity.

The normal subjects employed for these studies, P.L. and Y.G. [16], were chosen as representative because the insulin receptor on their cultured cells had been characterised in great detail in previous studies. Epstein-Barr virus transformed lymphocytes cell lines, established from peripheral blood lymphocytes as described previously, were grown in RPMI 1640 medium supplemented with 10\% fetal bovine serum (Bio-Fluid Laboratories Inc, Rockville, Md, USA) [9, 17].

\section{Cross-linking}

${ }^{125}$ I-Insulin was covalently cross-linked to insulin receptors on intact cells using $0.1 \mathrm{mmol} / 1$ disuccinimidyl suberate (Pierce Chemical Co., Rockford, Ill, USA) as described previously $[18,19]$. Cells were solubilized in $1 \%$ (volume/volume) Triton X-100 and the insoluble material was sedimented by centrifugation $\left(200,000 \mathrm{~g}\right.$ for $45 \mathrm{~min}$ at $\left.4^{\circ} \mathrm{C}\right)$. The supernatant was analyzed by SDS-polyacrylamide gel electrophoresis with or without prior reduction of disulfide bonds with $\beta$ mercaptoethanol ( $2.5 \%$ volume/volume). In some cases, the detergent extract was subjected to immunoprecipitation with $\alpha$-IR-1 monoclonal anti-insulin receptor antibody (an antibody with specificity to immunoprecipitate the insulin receptor with much greater

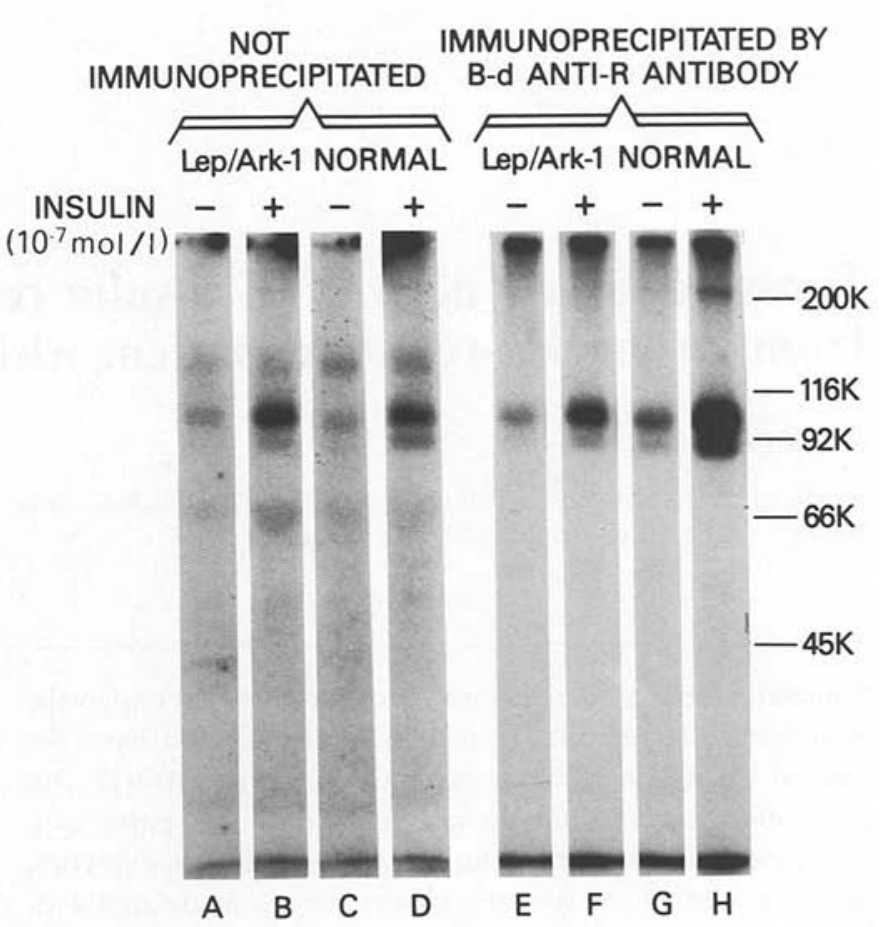

Fig. 2. Insulin-stimulated phosphorylation of the insulin receptor $\beta$ subunit. Partially purified preparations of insulin receptors from the normal subject (lanes C, D, G, H) and the patient (lanes A, B, E, F) were phosphorylated either in the absence (lanes $A, C, E, G$ ) or in the presence (lanes $\mathrm{B}, \mathrm{D}, \mathrm{F}, \mathrm{H}$ ) of $10^{-7} \mathrm{~mol} / 1$ insulin as described in Methods. Some samples of ${ }^{32} \mathrm{P}$-phosphoprotein were subjected to immunoprecipitation with B-d antireceptor antiserum (1:100 dilution) (lanes $\mathrm{E}-\mathrm{H}$ ). With other samples from the same experiment, immunoprecipitation was omitted (lanes A-D). After reduction of disulfide bonds by $\beta$-mercaptoethanol, the phosphoproteins were analyzed by SDS-polyacrylamide gel electrophoresis followed by autoradiography. In this experiment, receptor concentrations were adjusted to give ${ }^{125}$-I-insulin binding activity of approximately 0.24 (ratio of bound/free radioligand) assayed at an ${ }^{125}$ I-insulin concentration of $0.1 \mathrm{ng} / \mathrm{ml}$ for both leprechaun/Ark-1 and the normal subject. Note that the wheat germ agglutinin-agarose purified insulin receptor from leprechaun/Ark-1 has a normal binding affinity [10]

affinity than the IGF-I receptor) [20] prior to preparation for analytical SDS-polyacrylamide gel electrophoresis (Fig.1, lanes A, B). In some other cases, aliquots of the detergent extract were subjected to immunoprecipitation with anti-receptor antibody B-d [23] (Fig.4). Immunoprecipitated samples and corresponding supernatants were analyzed by SDS-polyacrylamide gel electrophoresis following reduction of disulfide bonds with $\beta$-mercaptoethanol $(2.5 \%$ volume/ volume). The radioactivity associated with the $\alpha$-subunit of the insulin receptor was determined by $\gamma$-counting.

\section{Wheat germ agglutinin-agarose chromatography}

Insulin receptors were partially purified by chromatography over wheat germ agglutinin-agarose according to the method of Hedo et al. [21]. Detergent extracts were applied to wheat germ agglutininagarose (Vector Laboratories, Burlingame, Calif, USA) (1 ml packed gel volume). The "flow-through" was reapplied to the column two additional times. The column was then washed with 80 volumes of wash buffer (Hepes, $50 \mathrm{mmol} / \mathrm{l}, \mathrm{pH} .7 .8 ; \mathrm{NaCl}, 150 \mathrm{mmol} / \mathrm{l}$; Triton $\mathrm{X}-100,0.1 \%$ volume/volume). Thereafter the receptors were eluted with six aliquots $(1 \mathrm{ml})$ of $\mathrm{N}$-acetyl-glucosamine $(0.3 \mathrm{~mol} / \mathrm{l})$ dis- 


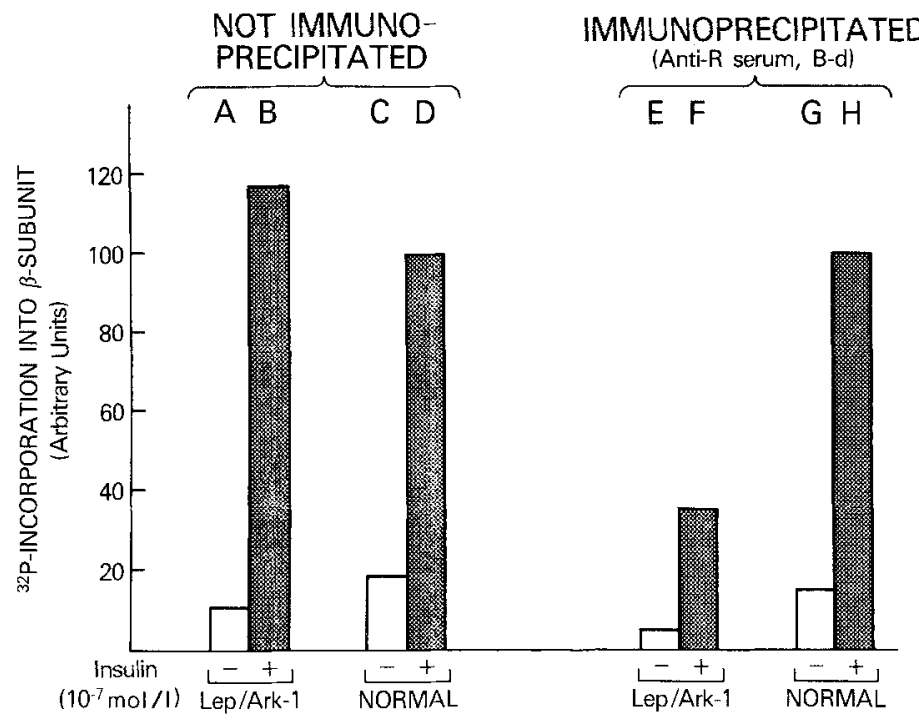

Fig. 3. ${ }^{32} \mathrm{P}$-incorporation into the $\beta$-subunit of insulin receptors with and without immunoprecipitation. The autoradiogram from Fig. 2 was subjected to scanning densitometry to quantitate the incorporation of ${ }^{32} \mathrm{P}$ into the insulin receptor $\beta$-subunit. With both the non-immunoprecipitated and the immunoprecipitated samples, the ${ }^{32} \mathrm{P}$ associated with the $\beta$-subunit of the insulin-stimulated normal receptor (lanes D and H, respectively) was assigned a value of 100 arbitrary units

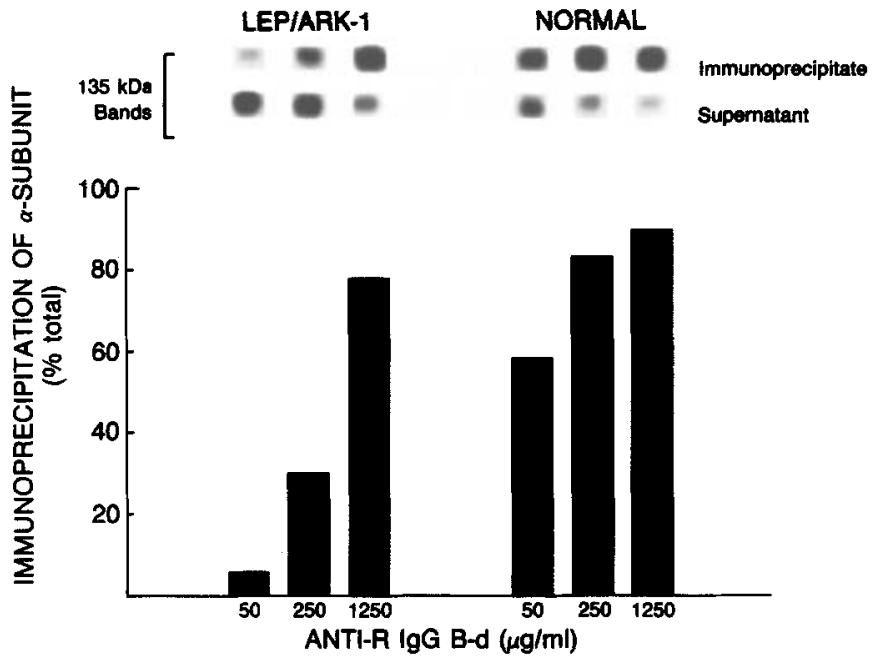

Fig.4. Immunoprecipitation of affinity-labelled insulin receptor by antibody B-d. Insulin receptors on cultured lymphocytes from leprechaun/Ark-1 and the normal subject were affinity labelled as described in Methods. The detergent extracts were immunoprecipitated using increasing amounts of IgG from anti-receptor antibody B-d. The IgG fraction from the serum was obtained by affinity chromatography over protein A-sepharose (Pharmacia, Upsalia, Sweden). The IgG concentration was determined spectrophotometrically [28]. Immunoprecipitated samples and corresponding supernatants were analyzed by SDS polyacrylamide electrophoresis after reduction of disulfide bonds by $\beta$-mercaptoethanol. Following autoradiography of the dried gel, the bands corresponding to the $\alpha$-subunits were excised (upper panel) and the associated radioactivity was determined by $\gamma$-counting. The results in the lower panel are expressed as the percentage of the radioactivity present in the $\alpha$-subunit of the immunoprecipitated samples as a function of the total radioactivity present in the $\alpha$-subunit of the immunoprecipitated samples and the supernatants solved in wash buffer. To determine whether receptors from leprechaun/Ark-1 interact normally with wheat germ agglutinin-agarose, we carried out wheat germ agglutinin affinity chromatography with affinity-labeled receptors from leprechaun/Ark-1 and a normal subject. There was no significant difference in the recovery of affinity-labeled insulin receptors from leprechaun/Ark-1 (53 $\pm 1 \%)$ and the normal subject $(56 \pm 6 \%)$. Recoveries were calculated by quantitation of the radioactivity associated with the receptor $\alpha$-subunit before and after chromatography over wheat germ agglutinin-agarose. The data are derived from three separate experiments, each with triplicate determinations.

\section{Phosphorylation}

Plasma membranes, prepared from $2 \times 10^{9}$ cells, were solubilised in $1 \%$ (volume/volume) Triton X-100 as described previously [10, 22]. The following protease inhibitors were added during the solubilisation procedure: phenylmethylsulfonyl fluoride $(2 \mathrm{mmol} / 1)$, aprotinin $(0.1 \mathrm{mg} / \mathrm{ml})$, leupeptin $(0.1 \mathrm{mg} / \mathrm{ml})$, pepstatin A $(0.1 \mathrm{mg} / \mathrm{ml}), \quad a_{2}$ macroglobulin $(0.5 \mathrm{U} / \mathrm{ml})$. After insoluble material was removed by centrifugation at $200,000 \mathrm{~g}$ for $45 \mathrm{~min}$, insulin receptors were partially purified by chromatography over wheat germ agglutinin-agarose (vide supra). ${ }^{125} \mathrm{I}$-insulin binding activity in the column eluates was measured at $4{ }^{\circ} \mathrm{C}$ as described previously [10]. Under these conditions, the wheat germ agglutinin-purified insulin receptors from leprechaun/Ark-1 have normal binding affinity [10]. Based on these measurements of ${ }^{125} \mathrm{I}$-insulin binding, we diluted the preparation of receptors to achieve equal concentrations of insulin receptor binding sites for both leprechaun/Ark-1 and the normal subject. Because there is considerable variation in receptor number even among normal subjects [12], it was necessary to equalise ${ }^{125}$ I-insulin binding activities (ratio of bound/free radioligand assayed at an ${ }^{125} \mathrm{I}$-insulin concentration of $0.1 \mathrm{ng} / \mathrm{ml}$ ) in the extract from cells of leprechaun/ Ark- 1 and the representative normal subject whose cells were studied simultaneously.

The receptor preparations were incubated either in the absence or in the presence of insulin (as specified in the legends) for $1 \mathrm{~h}$ at $24^{\circ} \mathrm{C}$ (or overnight at $4{ }^{\circ} \mathrm{C}$ for receptor autophosphorylation at $4{ }^{\circ} \mathrm{C}$ ). The phosphorylation reaction was initiated by the addition of $\mathrm{Mn}$ acetate $(6.8 \mu \mathrm{mol} / \mathrm{l})$, ATP $(6.8 \mathrm{mmol} / \mathrm{l})$, CTP $(1.3 \mathrm{mmol} / \mathrm{l})$ and $100 \mu \mathrm{Ci}$ of $\left[\gamma_{-}{ }^{32} \mathrm{P}\right] \mathrm{ATP}(2000 \mathrm{Ci} / \mathrm{mmol})$. After incubation at $24^{\circ} \mathrm{C}$ for $20 \mathrm{~min}$, the reaction was stopped by the addition of a "stopping solution" containing ATP (15 mmol/l), EDTA (16 mmol/l), NaF $(320 \mathrm{mmol} / \mathrm{l}), \mathrm{Na}$ pyrophosphate $(32 \mathrm{mmol} / \mathrm{l})$ and $\mathrm{Na}$ vanadate $(3.2 \mathrm{mmol} / \mathrm{l})$. We also studied receptor autophosphorylation at $4{ }^{\circ} \mathrm{C}$. The incorporation of ${ }^{32} \mathrm{P}$ was greatly reduced at the lower temperature; the magnitude of the reduction was similar with receptors from both the normal subject as well as leprechaun/Ark-1 (data not shown). Most studies were carried out at $24^{\circ} \mathrm{C}$ because the greater ${ }^{32} \mathrm{P}$ incorporation at that temperature facilitated the studies. For some experiments (Fig. 2, Lanes E-H), receptors were immunoprecipitated with anti-receptor antiserum B-d [23] prior to analysis by SDS-polyacrylamide gel electrophoresis. In other experiments, after addition of $5 \mathrm{X}$ concentrated Laemmli buffer [24], the samples were boiled and analyzed by SDS-polyacrylamide gel electrophoresis.

\section{Tyrosine kinase activity}

Tyrosine kinase activity was assayed according to the method of Grunberger et al. [28]. The wheat germ agglutinin-purified réceptor preparation $(20 \mu \mathrm{l})$ was incubated in the absence or the presence of insulin $\left(10^{-9}\right.$ to $\left.10^{-6} \mathrm{mmol} / \mathrm{l}\right)$ in a total volume of $30 \mu \mathrm{l}$ in a buffer containing Hepes $(50 \mathrm{mmol} / \mathrm{l} ; \mathrm{pH} 7.6)$ at $24^{\circ} \mathrm{C}$ for $1 \mathrm{~h}$ (Fig. 6). The reaction was initiated by addition of $40 \mu \mathrm{l}$ of the synthetic copolymer of glutamic acid plus tyrosine in a 4:1 ratio (poly glu:tyr) (Sigma Corp; St. Louis, Mo, USA) $(4 \mathrm{mg} / \mathrm{ml}), \mathrm{Mg} \mathrm{Cl}^{2}(10 \mathrm{mmol} / \mathrm{l})$, ATP $(100 \mu \mathrm{mol} / 1)$, and $15 \mu \mathrm{Ci}$ of $\left[\gamma_{-}{ }^{32} \mathrm{P}\right]$ ATP $(2000 \mathrm{Ci} / \mathrm{mmol})$ in a total volume of $90 \mu \mathrm{l}$. The reaction was stopped after $30 \mathrm{~min}$ by spotting $70 \mu 1$ of reaction mixture on filter paper (Whatman $3 \mathrm{MM}$ ) and immersing the paper in a solution of trichloracetic acid 10\% (weight/ volume) and sodium pyrophosphate $(10 \mathrm{mmol} / \mathrm{l})$. 


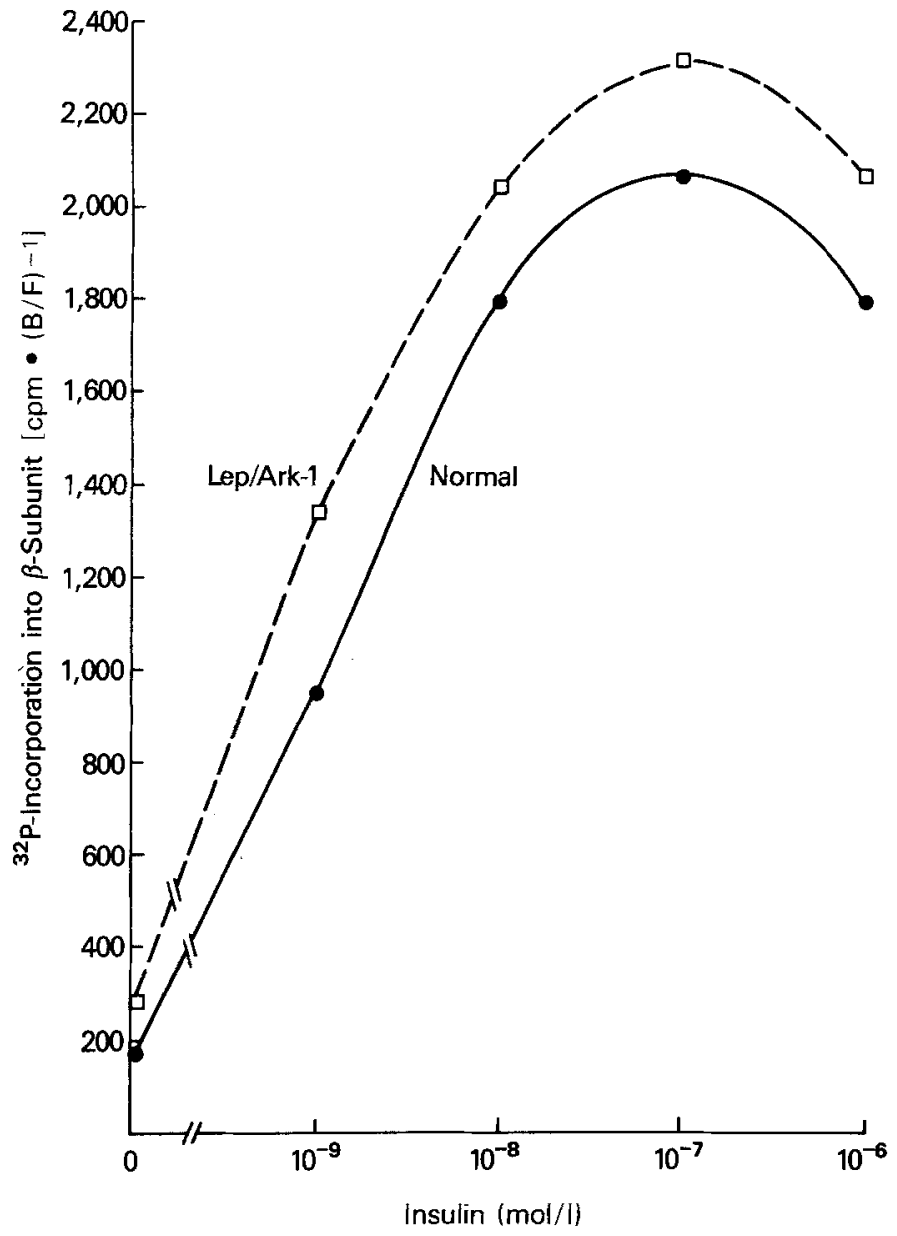

Fig.5. Dose-response curves for insulin stimulated phosphorylation of the insulin receptor $\beta$-subunit. Solubilized, partially purified insulin receptors from leprechaun/Ark-1 and the normal subject were phosphorylated in the absence or in the presence of insulin $\left(10^{-9}\right.$ to $10^{-6} \mathrm{~mol}$ ). The samples were analyzed by SDS-polyacrylamide gel electrophoresis followed by autoradiography. The radioactivity incorporated into the $\beta$-subunit was determined by excising the corresponding bands in the gel and counting them in a liquid scintillation counter. The results shown represent the mean of two different experiments. The ${ }^{125} \mathrm{I}$-insulin binding activities expressed as $\mathrm{B} / \mathrm{F}$ (ratio bound/free radioligand), of the receptor preparations used in the two separate experiments were $\mathrm{B} / \mathrm{F}=0.27$ (experiment $\mathrm{I}$ ) and $\mathrm{B} /$ $\mathrm{F}=0.16$ (experiment II) assayed at an ${ }^{125} \mathrm{I}$-insulin concentration of $0.1 \mathrm{ng} / \mathrm{ml}$

\section{Results}

\section{Cross-linking studies}

We employed affinity labelling techniques to study the oligomeric structure of the patient's insulin receptors and the molecular weight of the alpha subunit (Fig. 1). When the disulfide bonds in the receptor were reduced with $\beta$-mercaptoethanol prior to SDS-polyacrylamide gel electrophoresis, the major band was the alpha subunit with $M_{r}$ of approximately $130 \mathrm{kDa}$ (Fig.1, lanes A-B). In the experiment presented in Figure 1, the alpha subunit of receptors from leprechaun/Ark-1 had a slightly larger $M_{r}$ (approximately $5 \mathrm{kDa}$ ) than the normal insulin receptor. Although this difference

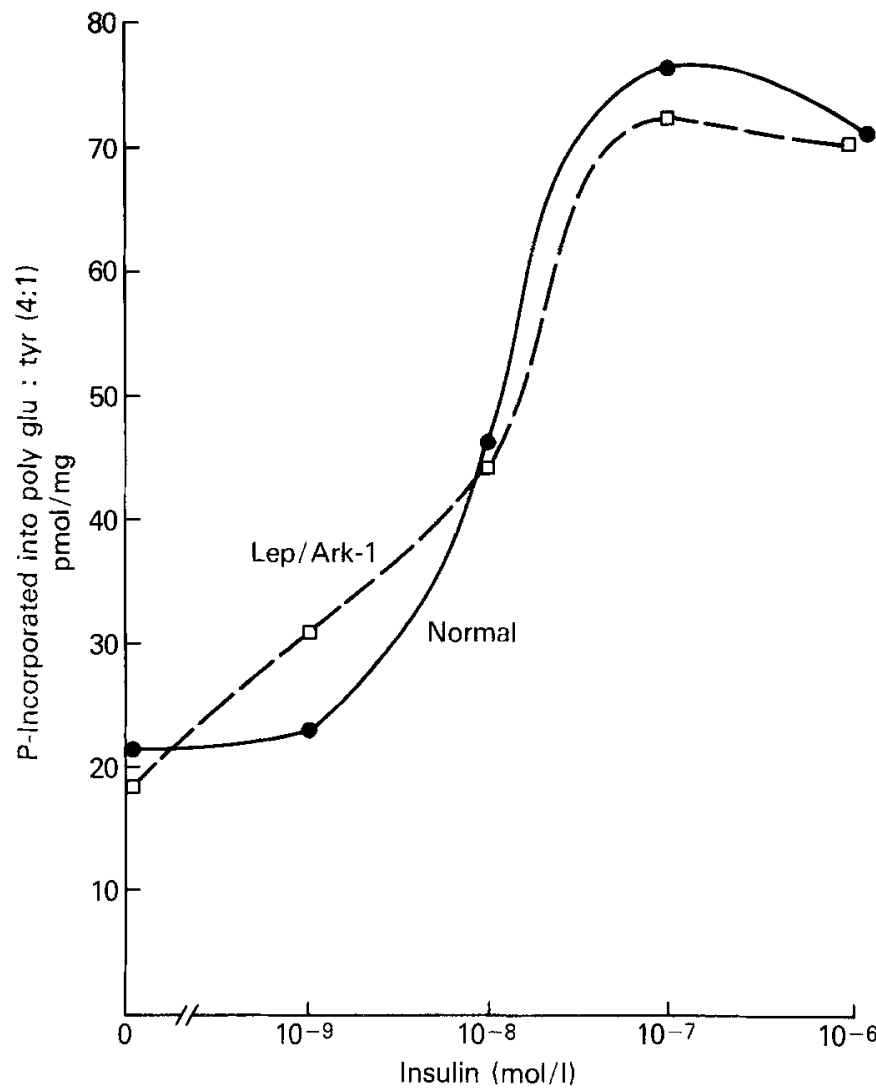

Fig. 6. Assay of the tyrosine kinase activity of the insulin receptor. Solubilized wheat germ agglutinin-agarose purified insulin receptors from leprechaun/Ark-1 and the normal subject were incubated in the presence of varying concentration of insulin (from 0 to $10^{6} \mathrm{~mol}$ / 1) for $1 \mathrm{~h}$ at $24^{\circ} \mathrm{C}$. Receptor concentrations were adjusted to give equal ${ }^{125}$ I-insulin binding activity for both the patient and the normal subject. The phosphorylation of the synthetic copolymer of glutamic acid plus tyrosine in a $4: 1$ ratio (poly glu:tyr) was analyzed as described in Methods. The results (mean of duplicate determination in two separate experiments) are expressed as pmol of phosphate per $\mathrm{mg}$ of poly glu : tyr substrate per unit of insulin binding activity in the course of $30 \mathrm{~min}$

was observed in several independent experiments, it was not entirely reproducible. With Epstein-Barr virustransformed lymphocytes from the normal subject, ${ }^{125}$ I-insulin also labeled a minor band with $M_{r}$ of approximately $250 \mathrm{kDa}$ (Fig. 1, lane A). This band appears to be a part of the insulin receptor, inasmuch as it was immunoprecipitated by a monoclonal anti-receptor antibody. As previously shown by Elsas et al. [15], this minor $250 \mathrm{kDa}$ band was not detected when cells from leprechaun/Ark-1 were affinity labeled (Fig. 1, lane B) although it was reproducibly detected with cells from all other subjects whom we have studied $(n=5$, data not shown).

When the insulin receptor was subjected to SDSpolyacrylamide gel electrophoresis without prior reduction of disulfide bonds, three oligomeric forms with apparent molecular weights of $430 \mathrm{kDa}, 340 \mathrm{kDa}$ and $230 \mathrm{kDa}$ were seen (Fig. 1, lanes C-D). The distribution of oligomeric forms is similar for receptors from both the normal subject and leprechaun/Ark-1. 


\section{Phosphorylation studies}

Because of the possibility that a defect in the receptorassociated tyrosine kinase activity might be associated with insulin resistance, we studied the kinase activity in insulin receptors from leprechaun/Ark-1. Partially purified insulin receptors were incubated with $\left[\gamma_{-}{ }^{32} \mathrm{P}\right] \mathrm{ATP}$ in the presence or the absence of insulin $\left(10^{-7} \mathrm{~mol} / 1\right)$. Phosphoproteins were analyzed by SDS-polyacrylamide gel electrophoresis either directly (Fig.2, lanes A-D) or after immunoprecipitation with antireceptor antiserum B-d (Fig. 2, lanes E-H). In all cases, insulin stimulated phosphorylation of a $95 \mathrm{kDa}$ band corresponding to the $\beta$-subunit of the insulin receptor.

In the study where the immunoprecipitation step was omitted, we observed that insulin stimulated the incorporation of ${ }^{32} \mathbf{P}$ into the $\beta$-subunit of receptors from leprechaun/Ark-1 at least was well as with receptors from the normal subject (Fig. 2, lanes A-D; Fig. 3). Moreover, antireceptor antiserum immunoprecipitated the ${ }^{32} \mathrm{P}$-labelled $\beta$-subunit only about one-third as well with receptors from leprechaun/Ark-1 as with receptors from the normal subject (Fig. 2, lanes E-H; Fig. 3). Studies with affinity-labelled receptors confirmed this result (Fig. 4). The lowest concentration of anti-receptor antibody B-d $(50 \mu \mathrm{g} / \mathrm{ml})$ immunoprecipitated 10 -fold more normal receptors as compared to receptors from leprechaun/Ark-1 (58\% versus 6\%). However, a 25-fold greater concentration of antibody $(1250 \mu \mathrm{g} / \mathrm{ml})$ immunoprecipitated $80-90 \%$ of both types of insulin receptors. This is consistent with the conclusion that anti-receptor IgG B-d recognises receptors from both normal subjects and leprechaun/ Ark-1, but that the receptor from leprechaun/Ark-1 is immunoprecipitated with 10 -fold lower avidity.

\section{Dose-response for autophosphorylation}

To further characterise the tyrosine kinase activity of the insulin receptor from leprechaun/Ark-1, we performed a dose-response study for the insulin stimulated phosphorylation of the insulin receptor (Fig. 5). Insulin appeared to stimulate the phosphorylation of the insulin receptor from leprechaun/Ark-1 in a similar fashion compared to the simultaneous control. The shape of the dose-response curves for phosphorylation of the $\beta$-subunits appears to be very similar for receptors from both the patient and the control. In fact, ${ }^{32} \mathrm{P}$ incorporation into the $\beta$-subunit from leprechaun/ Ark-1 appears to be slightly higher than from the control at each point in the curve.

\section{Dose response for tyrosine kinase activity}

We also studied the tyrosine kinase activity of the patient's receptors toward an exogenous substrate (Fig. 6). Insulin receptors from leprechaun/Ark-1 appeared to phosphorylate poly glu:tyr $(4: 1)$ substrate normally. The dose-response relationship of insulin-stimulated tyrosine kinase activity appears very similar with receptors from both leprechaun/Ark-1 and the normal subject.

\section{Discussion}

\section{Receptor-associated tyrosine kinase}

Recent evidence supports the hypothesis that the receptor-associated tyrosine kinase plays an important role in coupling insulin binding to insulin action [1-3]. Several patients have been described in whom insulin resistance is associated with a selective defect in receptor-associated tyrosine kinase activity [4-6]. In previous studies of Epstein-Barr virus-transformed lymphocytes from leprechaun/Ark-1, we have reported that insulin has a normal effect to stimulate receptor phosphorylation in intact cells [25]. However, as emphasised in that publication, we did not distinguish between tyrosinespecific phosphorylation catalyzed directly by the insulin receptor and phosphorylation of serine or threonine residues, presumably catalyzed by another protein kinase [26]. Furthermore, we did not investigate the doseresponse relationship for insulin stimulation of receptor phosphorylation. In the present study, we directly characterised the autophosphorylation activity of the solubilized, partially purified insulin receptor of leprechaun/Ark-1 under conditions where phosphorylation is predominantly on tyrosine residues [27]. Moreover, we characterised the tyrosine kinase activity of the patient's insulin receptor using the exogenous substrate poly glu:tyr ( $4: 1$ ratio). The autophosphorylation activity of the patient's receptor as well as the tyrosine kinase activity toward an exogenous substrate were stimulated normally by insulin. In particular, both the magnitude and dose-dependency of insulin's effects were normal. Although Epstein-Barr virus-transformed lymphocytes are not a physiological target for insulin action, we utilised these cells as a source of insulin receptors encoded by the patients insulin receptor genes. This should have enabled us to detect primary defects in the patient's insulin receptor which resulted from mutations of the insulin receptor gene. These observations suggest that this patient does not have a primary defect in the activity of the receptor-associated tyrosine kinase. Thus, it is possible that the insulin resistance is caused by a defect which compromises another, previously unrecognised, function of the receptor required for mediating insulin action.

\section{Receptor structure}

Our previous investigations demonstrated abnormal binding kinetics for insulin receptors from leprechaun/ Ark-1 [9-11]. Therefore, we have inferred that the receptors from this patient have an abnormal structure, possibly resulting from a mutation in the structural gene encoding the receptor. In the present work using 
antireceptor antibodies, we present immunological evidence consistent with our previous conclusion that the receptor is structurally abnormal, at least at the epitope(s) recognized by anti-receptor antiserum B-d (Figs. 2-4). In addition, some of our experiments have suggested that the affinity-labelled $\alpha$-subunit from receptors of leprechaun/Ark-1 may have slightly decreased mobility in SDS-polyacrylamide gel electrophoresis (Fig.1). This would also provide direct evidence of a structural abnormality in the $\alpha$-subunit of this patient's receptor. However, possibly because of limitations in the ability of SDS-polyacrylamide gel electrophoresis to resolve small differences in molecular weight, this observation was not completely reproducible. Finally, our studies with Epstein-Barr virustransformed lymphocytes confirmed previous observations of Elsas et al. [15] demonstrating an abnormal pattern when insulin receptors in the patient's fibroblasts were covalently cross-linked with disuccinimidyl suberate. With normal receptors, a minor band $\left(\mathrm{M}_{\mathrm{r}}=250 \mathrm{kDa}\right)$ is observed which is thought to represent an $\alpha-\alpha$ dimer [15]. This $\mathrm{M}_{\mathrm{r}}=250 \mathrm{kDa}$ band was not detected in cross-linking studies with receptors from leprechaun/Ark-1. This observation, suggesting a defect in the interactions between neighboring $\alpha$-subunits, is compatible with our previous studies demonstrating defects in the cooperative interactions between insulin binding sites [11].

\section{Heterogeneity of receptors}

Previously, we and others have suggested that this patient has inherited two different defective alleles causing insulin resistance, one from each parent $[12,15]$. This heterozygosity may give rise to two pools of insulin receptors, the existence of which potentially complicates our studies. Fortunately, the observation that the recovery of receptors from leprechaun/Ark-1 during chromatography over wheat germ agglutinin-agarose is normal makes it unlikely that the chromatographic procedure selectively enriches one pool of receptors. Nevertheless, the presence of two different pools of receptors might explain the results of our studies in which receptors were immunoprecipitated with anti-receptor antibodies. However, our data do not distinguish whether the decreased efficiency of immunoprecipitation of insulin receptors from leprechaun/Ark-1 results from a decrease in affinity to bind all of the patient's receptors or a selective decrease in affinity toward only one of the two pools.

The $\beta$-subunit of the IGF-I receptor has $\mathrm{M}_{\mathrm{T}}$ of approximately $95 \mathrm{kDa}$, and is bound with relatively low affinity by anti-insulin receptor antibodies. Thus, it is important to consider whether the ${ }^{32} \mathrm{P}$-labelled bands are derived from receptors for insulin or IGF-I. As previously reported, we have not detected receptors for IGF-I in Epstein-Barr virus-transformed lymphocytes [17]. Moreover, the dose-response relationship for insu- lin's effect to stimulate phosphorylation of both normal and leprechaun/Ark-1 receptors is characteristic of a receptor for insulin rather than IGF-I. Therefore, it is likely that the ${ }^{32} \mathrm{P}$-labelled bands with $\mathrm{M}_{\mathrm{r}}=95 \mathrm{kDa}$ correspond to the $\beta$-subunit of the insulin receptor.

\section{Anti-receptor antibodies}

Anti-receptor antibodies have been employed in many studies of the tyrosine kinase activity of insulin receptors from insulin resistant patients [4-6, 25]. In our study, we have identified a potential methodological pitfall in this approach. If the insulin resistant patient has structurally abnormal receptors, this abnormality may impair the ability of the antibodies to immunoprecipitate ${ }^{32}$ P-labelled receptors. Thus, if anti-receptor antibodies are to be used, it is important to employ sufficient quantities of an appropriate anti-receptor antibody to quantitatively immunoprecipitate both the abnormal receptor as well as the normal receptor.

Acknowledgements. We are grateful to Drs. P. Gorden and J. Roth for encouragement, advice and support, and to Drs. R. J.Comi, G.Grunberger, and N.Perrotti and Ms. B. Marcus-Samuels for helpful discussions. In addition, we are grateful to Dr. M. J. Elders for collaborating with us in the investigation of this patient and to Dr. S. Jacobs for generously providing monoclonal antibody $\alpha-\mathrm{IR}-1$. Finally, we wish to thank Mrs. S. Ogoh and Ms. C.Culwell for expert secretarial assistance in preparation of this manuscript.

\section{References}

1. Kasuga M, Karlsson FA, Kahn CR (1982) Insulin stimulates the phosphorylation of the 95,000 -dalton subunit of its own receptor. Science 215: 185-187

2. Morgan DO, Ho L, Korn LJ, Roth RA (1986) Insulin action is blocked by a monoclonal antibody that inhibits the insulin receptor kinase. Proc Natl Acad Sci USA 83: 328-332

3. Ellis L, Clauser E, Morgan DO, Edery M, Roth RA, Rutter WJ (1986) Replacement of insulin receptor tyrosine residues 1162 and 1163 compromises insulin stimulated kinase activity and uptake of 2-deoxyglucose. Cell 45: 712-732

4. Grunberger G, Zick Y, Gorden P (1984) Defect in phosphorylation of cells from an insulin-resistant patient with normal insulin binding. Science 223: 932-934

5. Grigorescu F, Flier JS, Kahn CR (1984) Defect in insulin receptor phosphorylation in erythrocytes and fibroblasts associated with severe insulin resistance. J Biol Chem 259: 15003-15006

6. Grigorescu F, Flier JS, Kahn CR (1986) Characterization of binding and phosphorylation defects of erythrocyte insulin receptors in the Type A syndrome of insulin resistance. Diabetes 35: $127-138$

7. Caro JF, Ittoop O, Pories WJ, Meelhelm D, Flickinger EG, Thomas F, Jenquin M, Silverman J, Khazanie PG, Sinha MK (1986) Studies on the mechanism of insulin resistance in the liver from humans with noninsulin-dependent diabetes. J Clin Invest 76: 249-258

8. Comi RJ, Grunberger G, Gorden P (1987) Relationship of insulin binding and insulin-stimulated tyrosine kinase activity is altered in type II diabetes. J Clin Invest 79: 453-462

9. Taylor SI, Roth J, Blizzard RM, Elders MJ (1981) Qualitative abnormalities in insulin binding in a patient with extreme insulin resistance: decreased sensitivity to alterations in temperature and pH. Proc Natl Acad Sci USA 78: 7157-7161 
10. Taylor SI, Hedo JA, Underhill LH, Kasuga M, Elders MJ, Roth J (1982) Extreme insulin resistance in association with abnormally high binding affinity of insulin receptors in a patient with leprechaunism: evidence for a defect intrinsic to the receptor. J Clin Endocrinol Metab 55: 1108-1113

11. Taylor SI, Leventhal S (1983) Defect in cooperativity in insulin receptors from a patient with a congenital form of extreme insulin resistance. J Clin Invest 71: 1676-1685

12. Taylor SI, Marcus-Samuels B, Ryan-Young J, Leventhal S, Elders MJ (1986) Genetics of the insulin receptor defect in a patient with extreme insulin resistance. J Clin Endocrinol Metab 62: $1130-1135$

13. Kobayashi M, Olefsky JM, Elders M, Mako ME, Given BD, Schedewie HK, Fiser RH, Hintz RL, Horner JA, Rubenstein AH (1978) Insulin resistance due to a defect distal to the insulin receptor: demonstration in a patient with leprechaunism. Proc Natl Acad Sci USA 75: 3469-3473

14. Elders MJ, Schedewie HK, Olefsky J, Givens B, Char F, Bier DM, Baldwin D, Fiser RH, Seyedabadi S (1982) Endocrinemetabolic relationships in patients with leprechaunism. J Natl Med Assoc 74: 1195-1210

15. Elsas LJ, Endo F, Strumlauf E, Elders J, Priest JH (1985) Leprechaunism: an inherited defect in a high-affinity insulin receptor. Am J Hum Genet 37: 73-88

16. Hedo JA, Moncada VY, Taylor SI (1985) Insulin receptor biosynthesis in cultured lymphocytes from insulin-resistant patients. J Clin Invest 76: 2355-2361

17. Taylor SI, Samuels B, Roth J, Kasuga M, Hedo JA, Gorden P, Brasel DE, Pokora T, Engel RR (1982) Decreased insulin binding in cultured lymphocytes from two patients with extreme insulin resistance. J Clin Endocrinol Metab 54: 919-930

18. Pilch PF, Czech M (1979) Interaction of cross-linking agents with the insulin effector system of isolated fat cells. J Biol Chem 254: 3375-3381

19. Taylor SI, Schroer JA, Marcus-Samuels B, McElduff A, Bender TP (1984) Binding of insulin to its receptor impairs recognition by monoclonal anti-insulin antibodies. Diabetes $33: 778-784$

20. Kull FC, Jacobs S, Su YF, Svoboda ME, van Wyk JJ, Cuatrecasas $\mathrm{P}$ (1983) Monoclonal antibody to receptors for insulin and somatomedin-C. J Biol Chem 258: 6561-6566
21. Hedo JA, Harrison LC, Roth J (1981) Binding of insulin receptors to lectins: evidence for common carbohydrate determinants on several membrane receptors. Biochemistry 20: 3385-3393

22. Jett M, Seed TM, Jamieson GA (1977) Isolation and characterization of plasma membranes and intact nuclei from lymphoid cells. J Biol Chem 252: 2134-2142

23. Taylor SI, Marcus-Samuels B (1986) Anti-receptor antibodies mimic the effect of insulin to down-regulate insulin receptors in cultured human lymphoblastoid (IM-9) cells. J Clin Endocrinol Metab 58: 182-186

24. Laemmli VK (1970) Cleavage of structural proteins during the assembly of the head of bacteriophage $T_{4}$. Nature 1227:680-685

25. Whittaker J, Zick Y, Roth J, Taylor SI (1985) Insulin stimulated receptor phosphorylation appears normal in cultured EpsteinBarr virus-transformed lymphocyte cell lines derived from patients with extreme insulin resistance. $\mathrm{J}$ Clin Endocrinol Metab 60: $381-386$

26. Kasuga M, Hedo JA, Yamada KM, Kahn CR (1982) The structure of insulin receptor and its subunits. Evidence for multiple nonreduced forms and a 210,000 possible proreceptor. J Biol Chem 257: 10392-10399

27. Kasuga M, Zick Y, Blithe DL, Crettaz M, Kahn CR (1982) Insulin stimulates tyrosine phosphorylation of the insulin receptor in a cell-free system. Nature 298: 667-669

28. Grunberger G, Zick Y, Roth J, Gorden P (1983) Protein kinase activity of the insulin receptor in human circulating and cultured mononuclear cells. Biochem Biophys Res Commun 115: 560-566

29. Layne E (1957) Spectrophotometric and turbidimetric methods for measuring proteins. Methods Enzymol 109: 656-667

Received: 30 December 1986

and in revised form: 10 June 1987

Dr. Simeon I. Taylor

National Institutes of Health

Building 10, Room 8 N250

Bethesda, Maryland 20892

USA 